\title{
Floristic Composition, Structure and Soil Properties of Mixed Deciduous Forest and Deciduous Dipterocarp Forest: Case Study in Madan Watershed, Myanmar
}

\author{
Kyaw Kyaw Myo', San Thwin², Nyunt Khaing² \\ ${ }^{1}$ Forest Department, Head Office of Ministry of Environmental Conservation and Forestry, Nay Pyi Taw, \\ Myanmar \\ ${ }^{2}$ Department of Forestry, University of Forestry, Yezin, Nay Pyi Taw, Myanmar \\ Email: myokk94@gmail.com, santhwin@gmail.com, nyuntkhaing@googlemail.com
}

Received 18 December 2015; accepted 15 February 2016; published 18 February 2016

Copyright (C) 2016 by authors and Scientific Research Publishing Inc.

This work is licensed under the Creative Commons Attribution International License (CC BY).

http://creativecommons.org/licenses/by/4.0/

(c) (i) Open Access

\section{Abstract}

Patterns of woody regeneration in terms of species composition and diversity were studied in mixed deciduous forest (MDF) and deciduous dipterocarp forest (DDF) in Minbyin reserved forest of Lewe Township. A total of 57 plant species of MDF belonging to 28 families and 342 individuals and 25 plant species of DDF consist of 15 families and 285 individuals were identified. Plant species diversity was quantitatively higher in the MDF $\left(H^{\prime}=3.68\right)$ compared to the DDF $\left(H^{\prime}=2.39\right)$. Tectona grandis showed the highest density (30), dominance $\left(4.40 \mathrm{~m}^{2}\right)$ and IVI (27.01) of MDF and Dipterocarpus tuberculatus also composed the highest density (109), dominance $\left(9.02 \mathrm{~m}^{2}\right)$ and IVI (81.87) in DDF. The smallest diameter class $(10-20 \mathrm{~cm})$ comprised with 29 species, 103 individuals in MDF and 18 species, 85 individuals in DDF. The size class distribution displayed a reverse J-shaped pattern. The largest numbers of species were concentrated in the smallest height class in both investigated forests because of height and diameter distribution is closely related. The total densities of seedlings and saplings were 1219 and $531 \mathrm{ha}^{-1}$ in MDF and 988 and $444 \mathrm{ha}^{-1}$ in DDF respectively. Although soil texture of $(40-50 \mathrm{~cm})$ and $(90-100 \mathrm{~cm})$ were sandy clay loam in mixed deciduous forest, the other layers of both investigated forests were sandy loam.

\section{Keywords}

Floristic Composition and Structure, Mixed Deciduous Forest, Deciduous Dipterocarp Forest, Regeneration, Soil Properties 


\section{Introduction}

The watershed forests are a vital role to protect watershed area in Myanmar because there are different kinds of challenges facing serious floods and landslides in some regions. It is clear that linkage between floristic composition, forest stand structure, soil physical and chemical properties results outcomes are useful to catchment regions' restoration measures in order to achieve sustainability of forests in long run. Moreover, ecological data need to be obtained for the application of effective management practices in the watershed forests. Floristic composition and structure studies are essential for their values in understanding the extent of plant biodiversity in forest ecosystems [1] as well as in watershed forests. This study was intended to provide for linkage between species composition, stand structure and soil properties of forest dynamics and floristic changes in the watershed areas. An assessment of composition and structure of selected forest types will follows, concluded with an assessment of the potential and possibilities for future forest management. Floristic composition, structure and natural regeneration of the forests in watersheds are critical to known in the present day. Many currently successful forest management and restoration plans base on accurate and detailed characterization of the plant community, i.e. its species composition [2]. This may include the number of species present, but often takes into account quantitative measures such as abundance, frequency, density, coverage, and basal area [3]. Measures of diversity such as the Shannon and Simpson indices have also been useful for specifying and comparing forest communities [4]. Soils are important to life on earth and the quality of the soil determines the nature of plant ecosystems and the capacity of land to support animal life and society [5]. Soil properties are partially dependent on forest types which directly affect vegetation [6].

\section{Material and Method}

\subsection{Study Area}

The study area was selected Minbyin reserved forest of Lewe Township, Myanmar (latitude $19^{\circ} 28^{\prime} 35 " \mathrm{~N}$ and longitude 9550'37"E).

\subsection{Data Collection}

The data were collected in November, 2013. Eight plots were established in two different forest types within the reserved forest. In each forest type, four $50 \times 50 \mathrm{~m}(\mathrm{~A})$ plots were randomly set up. Each plot was subdivided into four $10 \times 10 \mathrm{~m}$ (B) plots in the corner of plot (A). In subplot (A) $2500 \mathrm{~m}^{2}(50 \mathrm{~m} \times 50 \mathrm{~m})$, all trees with DBH $\geq 10 \mathrm{~cm}$ were recorded and the following variables were measured for all trees: species, number of individuals, height and DBH. In subplot (B) $100 \mathrm{~m}^{2}(10 \mathrm{~m} \times 10 \mathrm{~m})$ saplings with height $>130 \mathrm{~cm}$, DBH $<10 \mathrm{~cm}$ and seedlings $(0.3 \mathrm{~m}<$ height $\leq 1.3 \mathrm{~m})$ were recorded. Soil samples were collected at three different soil depths in every sample plots. The average crown cover is measured by crown widths and crown lengths.

\subsection{Data Analysis}

The diversity of plant species in the forest types was quantified using the Shanon (H) and Simpson (1-D) species diversity indices. The Sorensen, Weidelt, Bray and Curits similarities indices were used for comparison between the two different forest types. Important-Value-Index was used to compare ecological significance of species. It combined data for three parameters (relative abundance, relative frequency and relative dominance). Tree species were identified by using a guide book of "A Checklist of the trees, Shrubs, Herbs, and Climbers of Myanmar”, [7]. Soil samples were analyzed by "Manual of Laboratory Procedure" [8]. The collected data were analyzed by using Excel 2007 and STATISTICA 7 for window.

\section{Results}

\subsection{Floristic Composition, Species Diversity and Similarity}

Table 1 shows Diversity indices and evenness, DBH $\geq 10 \mathrm{~cm}$ of two forest types. Table 2 shows value of coefficient of similarity by SORENSEN (Ks), WEIDELT (Kd) and BRAY and CRTIS (CN).

According to the results by calculating Shanon diversity index (H') [9] and Simpson index (D) [10], mixed deciduous forest is more heterogeneous than deciduous dipterocarp forest. The value of $\mathrm{D}$ decreases while di- 
Table 1. Diversity indices and evenness, $\mathrm{DBH} \geq 10 \mathrm{~cm}$.

\begin{tabular}{ccc}
\hline Diversity indices & MDF & DDF \\
\hline Shannon index (H') & 3.68 & 2.39 \\
Simpson index (1-D) & 0.97 & 0.83 \\
Shanon evenness & 91.16 & 74.28 \\
\hline
\end{tabular}

Table 2. Coefficient of similarity indices value.

\begin{tabular}{cc} 
Coefficient of similarity indices & Value (\%) $(\mathrm{DBH} \geq 10 \mathrm{~cm})$ \\
\hline Sorensen (Ks) & 46.34 \\
Weidelt (Kd) & 42.49 \\
Bray \& Curtis (CN) & 78.15 \\
\hline
\end{tabular}

versity increases [11]. It can be observed that the species in mixed deciduous forest is more diverse than deciduous dipterocarp forest. Evenness refers to how the species abundance is distributed among the species [12]. The values of Shanon evenness shows that the abundance of species are more even in mixed deciduous forest than deciduous dipterocarp forest.

The results show slightly above a moderate floristically similarity between mixed deciduous forest and deciduous dipterocarp forest according to Sorensen's index of similarity [13] and Weidelt [14]. However similarity by Bray and Curtis [15] indicate that the floras of the two investigated forests are more similar with each other.

\subsection{Abundance, Dominance, Frequency and IVI of Both Investigated Forests}

Abundance, dominance, frequency and Importance Value Index of the lists of 9 species ranged based on their IVI for the investigated forests are shown in Table 3 and Table 4. Tectona grandis had the highest abundance, dominance, frequency and IVI in mixed deciduous forest. The dominance of Tectona grandis was 14.73\% of the total basal area of all species. In deciduous dipterocarp forest, Dipterocarpus tuberculatus was the highest abundance, dominance, frequency, IVI and occupied 35.63\% of the total basal area of all species. The second most abundance species was Xylia xylocapa $10.10 \%$ of total dominance of all species in mixed deciduous forest. The second most abundance species of deciduous dipterocarp forest was Shorea siamensis and 14.62\% of total dominance of all species. Termminalia alata and Schleichera oleosa species were occurred $8.44 \%$ and $3.82 \%$ in mixed deciduous forest and $9.99 \%$ and $2.97 \%$ in deciduous dipterocarp forest of total basal area. There are 35 species with relative abundance value below $2 \%$ in mixed deciduous forest and 12 species in deciduous dipterocarp forest respectively. Many species in the investigated forests have low abundance, low frequency and low dominance value. These species of both forests are rare casual and no major ecological or economic significance [16]. The most abundance species usually have high frequency values, i.e., they belong to the group of tree species with a regular horizontal distribution [16]. It can be observed that only few species were most abundance and had high frequency values in the investigated forests but most of species are comparatively causal. In mixed deciduous forest Tectona grandis, Xylia xylocapa, Milettia pendula were found to be the most abundance species with the high frequency values of $100 \%$ and Dipterocarpus tuberculatus, Shorea siamensis, Shorea oblongifolia in deciduous dipterocarp forest. This indicated favorable site condition for the development of them. It can also be assumed that these trees had regular horizontal distribution. It can be investigated that there is a close relationship between abundance and frequency values in both frorests.

In both investigated forests, it can be observed that rare species are present with a low abundance value. There are 11 species with only one individual in mixed deciduous forest and 4 species in deciduous dipterocarp forest. As abundance and frequency values are closely related to each other, rare species had low frequency values. The dominance of rare species is $3.49 \%$ of total basal area in mixed deciduous forest and $0.61 \%$ in deciduous dipterocarp forest. 
Table 3. Abundance, dominance, frequency and IVI of the species in MDF, DBH $\geq 10 \mathrm{~cm}, 1$ ha.

\begin{tabular}{|c|c|c|c|c|}
\hline Species name & Abundance (No. of trees) & Dominance (BA) & Frequency (\%) & IVI \\
\hline Tectona grandis & 30 & 4.40 & 100 & 27.01 \\
\hline Xylia xylocapa & 23 & 3.02 & 100 & 20.33 \\
\hline Milettia pendula & 17 & 2.12 & 100 & 15.57 \\
\hline Terminalia alata & 11 & 2.52 & 100 & 15.17 \\
\hline Schleichera oleosa & 10 & 1.14 & 100 & 10.25 \\
\hline Legerstromemia villosa & 15 & 0.69 & 100 & 10.21 \\
\hline Mitragyna rotundifolia & 12 & 0.67 & 100 & 9.26 \\
\hline Salmalia insignis & 3 & 1.72 & 75 & 9.25 \\
\hline Delbergia cultrata & 10 & 0.87 & 75 & 8.45 \\
\hline Others (48) & 211 & 12.75 & 2000 & 174.50 \\
\hline Total (57) & 342 & 29.89 & 2850 & 300.00 \\
\hline
\end{tabular}

Table 4. Abundance, dominance, frequency and IVI of the species in DDF, DBH $\geq 10 \mathrm{~cm}, 1$ ha.

\begin{tabular}{|c|c|c|c|c|}
\hline Species name & Abundance & Dominance & Frequency \% & IVI \\
\hline Dipterocarpus tuberculatus & 109 & 9.02 & 100 & 81.87 \\
\hline Shorea siamensis & 27 & 3.70 & 100 & 32.09 \\
\hline Shorea oblongifolia & 21 & 2.46 & 100 & 25.08 \\
\hline Terminalia alata & 19 & 2.53 & 100 & 24.65 \\
\hline Xylia xylocapa & 15 & 1.06 & 75 & 15.25 \\
\hline Melanorrhoea usitata & 13 & 0.81 & 75 & 13.76 \\
\hline Schleichera oleosa & 8 & 0.75 & 75 & 11.78 \\
\hline Delbergia cultrata & 8 & 0.75 & 50 & 9.78 \\
\hline Buchanania lanzan & 9 & 0.35 & 50 & 8.54 \\
\hline Others (16) & 56 & 3.88 & 525 & 77.00 \\
\hline Total (25) & 285 & 25.31 & 1250 & 300 \\
\hline
\end{tabular}

\subsection{Diameter Frequency Class and Distribution of Individuals by Height Class}

Figure 1 shows that the distribution of individuals of both forests by diameter class. According to this figure, the numbers of trees occurred in lower diameter classes than higher diameter classes. This indicated that the reserve of small diameter trees in moist tropical forest was in any case adequate to replace the losses in large diameter classes. Therefore natural sustained yield was therefore evidently completely assured [16].

Tectona grandis and Dipterocarpus tuberculatus trees were the dominance species in terms of tree density and basal area in mixed deciduous forest and deciduous dipterocarp forest. The deciduous dipterocarp forest was less number of trees in the smaller diameter classes as compared to the mixed deciduous forest. It was depended on different forest types. The mixed deciduous forest occupied more growth stages and numbers of species than deciduous dipterocarp forest because of site conditions were favorable.

The distributions of individuals and species were similar in diameter classes. The larger numbers of species were concentrated in lower diameter classes up to middle diameter classes while only few numbers of species were found in higher diameter classes. It was found that 51\% (29 species) in mixed deciduous forest and $72 \%$ (18 species) in deciduous dipterocarp forest were present in the class of dbh $(10-20) \mathrm{cm}$. 


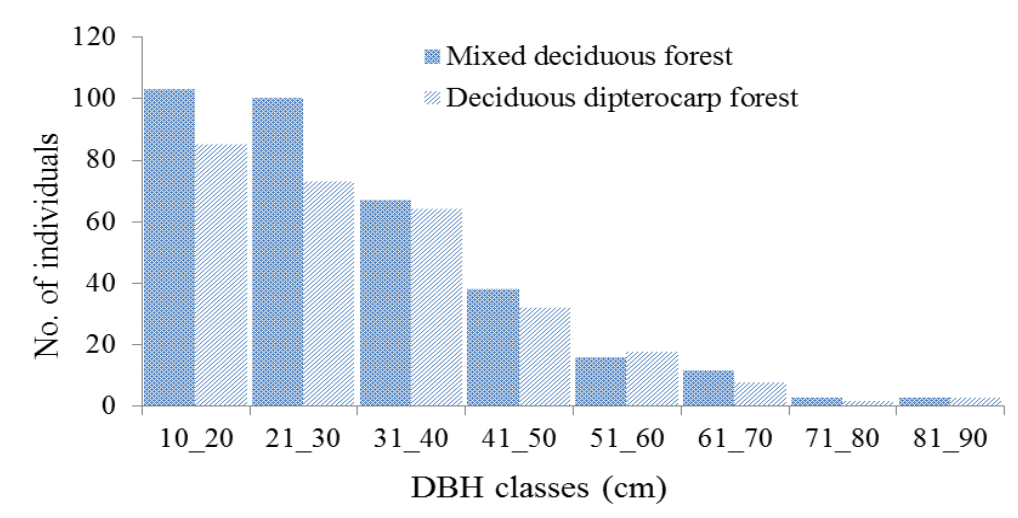

Figure 1. Distribution of DBH.

Figure 2 shows the distribution of individuals by height classes. The individuals of both forests decrease with increasing height classes because diameter and height of trees are closely related. The individuals of mixed deciduous forest and deciduous dipterocarp forest were concentrated in the lowest respective height class approximately $31 \%$ and $34 \%$ of total individuals. It is because of their different forest types and soils. In mixed deciduous forest, the dominant trees of height $\geq 22 \mathrm{~m}$ are $5 \%$ of total stands, but small number of individuals in deciduous dipterocarp forest in such classes with only $4 \%$.

\subsection{Natural Regeneration}

The composition, distribution and density of seedlings and saplings reveal the future status of the forest. Seed production must be adequate to ensure more or less uninterrupted availability of viable seeds of several species [16]. The other important factors for germination and establishment of seedlings are climatic and edaphic conditions. The total density of seedlings, saplings and trees were 1219, 531 and $342 \mathrm{ha}^{-1}$ in mixed deciduous forest and 988, 444 and $285 \mathrm{ha}^{-1}$ in deciduous dipterocarp forest respectively.

\subsection{Forest Soils}

\subsubsection{Physical Properties of Soils}

Table 5 shows soil physical properties based on soil layers in mixed deciduous forest and deciduous dipterocarp forest. In both study sites a one-meter deep soil pit was dug to analyze and compare soil parameters. Soil samples were extracted from the following soil depths: $0-10 \mathrm{~cm}, 40-50 \mathrm{~cm}$ and $90-100 \mathrm{~cm}$ from each soil pit. The physical properties of soils determine their adaptability for trees and the level of biological activity that can be provided by the soil. Soil physical properties also mostly determine the soil's water and air supplying capacity to plants.

Mixed deciduous forest had a higher soil moisture content compared to deciduous dipterocarp forest. As the amount of clay-sized particles content of mixed deciduous forest were higher than deciduous dipterocarp forest, moisture content more retained in mixed deciduous forest. The deciduous dipterocarp forest had lower vegetation cover but higher bulk density than mixed deciduous forest. The average sand content of different layers (53\%) was observed under the mixed deciduous forest and (70\%) was recorded in the deciduous dipterocarp forest. The average silt fractions of the mixed deciduous forest and the deciduous dipterocarp forest were $25 \%$ and $12 \%$, the clay fractions were $20 \%$ and $14 \%$, respectively.

\subsubsection{Chemical Properties of Soils}

Table 6 shows soil chemical properties based on soil layers in mixed deciduous forest and deciduous dipterocarp forest. Soil chemical properties are the most important factors and determine the nutrient supplying power of the soil to the plants. The soil chemical reactions affect the processes that leading to soil development and soil fertility build up.

Minerals inherited from the soil parent materials overtime give up chemical elements that undergo various changes and transformations within the soil. Soil $\mathrm{pH}$ values of investigated forests were not significantly different. The maximum soil $\mathrm{pH}$ values were occurred in $90-100 \mathrm{~cm}$ depth and the minimum soil $\mathrm{pH}$ values 


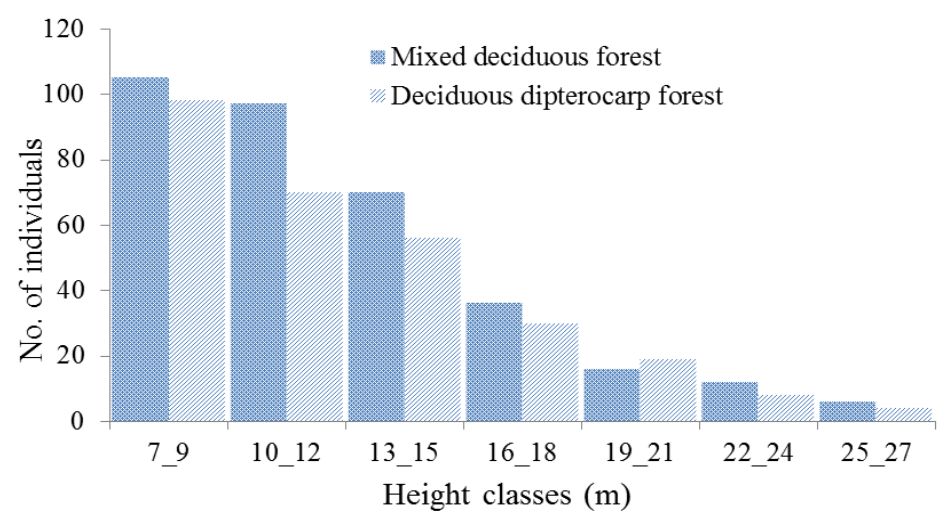

Figure 2. Distribution of height.

Table 5. Soil physical properties of mixed deciduous forest and deciduous dipterocarp forest.

\begin{tabular}{|c|c|c|c|c|c|c|c|}
\hline Forest types & Depth [cm] & Moisture & Bulk density & Sand [\%] & Silt [\%] & Clay [\%] & Texture \\
\hline \multirow{3}{*}{$\begin{array}{l}\text { Mixed } \\
\text { deciduous } \\
\text { forest }\end{array}$} & $0-10$ & 26.75 & 1.219 & 56.75 & 25.50 & 16.00 & Sandy loam \\
\hline & $40-50$ & - & - & 51.75 & 26.00 & 22.25 & Sandy clay loam \\
\hline & $90-100$ & - & - & 50.25 & 23.50 & 20.50 & Sandy clay loam \\
\hline \multirow{3}{*}{$\begin{array}{l}\text { Deciduous } \\
\text { dipterocarp } \\
\text { forest }\end{array}$} & $0-10$ & 19.37 & 1.32 & 69.00 & 12.25 & 13.50 & Sandy loam \\
\hline & $40-50$ & - & - & 69.50 & 11.75 & 15.25 & Sandy loam \\
\hline & $90-100$ & - & - & 70.25 & 11.50 & 13.50 & Sandy loam \\
\hline
\end{tabular}

Table 6. Soil chemical properties of mixed deciduous forest and deciduous dipterocarp forest.

\begin{tabular}{ccccccc}
\hline Forest type & Depth $[\mathrm{cm}]$ & $\mathrm{pH}$ & Total N \% & Ava. P \% & Exc. K \% & OM \% \\
\hline Mixed deciduous forest & $0-10$ & 6.08 & 0.059 & 0.00030 & 0.0087 & 0.0047 \\
& $40-50$ & 6.05 & 0.054 & 0.00009 & 0.0042 \\
Deciduous dipterocarp forest & $90-100$ & 6.13 & 0.050 & 0.00015 & 0.0080 \\
& $0-10$ & 6.05 & 0.029 & 0.00018 & 0.0047 \\
\hline
\end{tabular}

were found in the depth of $40-50 \mathrm{~cm}$ of both investigated forests. The same values of soil $\mathrm{pH}$ were found in 40 - $50 \mathrm{~cm}$ of mixed deciduous forest and $0-10 \mathrm{~cm}$ of deciduous dipterocarp forest. However, $\mathrm{pH}$ values of every soil layers of mixed deciduous forest were higher than deciduous dipterocarp forest. The mixed deciduous forest had higher organic matter than deciduous dipterocarp forest in every depths of soil. The organic matter of mixed deciduous forest and deciduous dipterocarp forest were $3.53 \%$ and $2.07 \%$ in $0-10 \mathrm{~cm}$. The organic matter of the two forests gradually decreased as the range of soil layers $0-10 \mathrm{~cm}, 40-50 \mathrm{~cm}$ and $9-100 \mathrm{~cm}$. But the lowest organic matter $2.59 \%$ in $90-100 \mathrm{~cm}$ of mixed deciduous forest was higher than the highest organic matter $2.07 \%$ in $0-10 \mathrm{~cm}$ of deciduous dipterocarp forest. The mean total nitrogen concentrations of mixed deciduous forest and deciduous dipterocarp forest were $0.054 \%$ and $0.026 \%$ respectively. The mean values of phosphorus and potassium of mixed deciduous forest were higher than those of deciduous dipterocarp forest.

\subsection{Relationship between Vegetation Parameters and Soil Variables}

Table 7 shows relationship between tree basal area and soil variables (pH, OM, MC, BD) of mixed deciduous forest and deciduous dipterocarp forest. The $\mathrm{BA}$ and $\mathrm{pH}, \mathrm{OM}, \mathrm{MC}$ of mixed deciduous forest were not significantly related. The BA and soil bulk density of mixed deciduous forest were direct significantly related at $P<$ 0.01 . The $\mathrm{BA}$ and $\mathrm{pH}$ were direct significantly related at $P<0.05$ and $\mathrm{BA}$ and $\mathrm{MC}$ were inverse significantly related at $P<0.05$ but BA and $\mathrm{OM}, \mathrm{BD}$ were not significantly related in deciduous dipterocarp forest.

Table 8 shows relationship between crown cover and soil variables (pH, OM, MC, BD) of mixed deciduous 
Table 7. Relationship between basal area and soil variables.

\begin{tabular}{cccccc}
\hline Categories & & $\mathrm{a}$ & $\mathrm{b}$ & $\mathrm{r}$ & $P$ \\
\hline Mixed deciduous forest & $\mathrm{pH}$ & 13.0317 & -0.9138 & 0.4196 & 0.3522 \\
& $\mathrm{OM}$ & 7.0589 & 0.1392 & 0.1569 & 0.6039 \\
Deciduous dipterocarp forest & $\mathrm{MC}$ & 7.4139 & 0.0022 & 0.0017 & 0.9583 \\
& $\mathrm{BD}$ & 15.156 & -6.3099 & 0.9673 & $0.0165^{* *}$ \\
& $\mathrm{pH}$ & -2.15 & 1.3997 & 0.9184 & $0.0417^{*}$ \\
& $\mathrm{OM}$ & 6.4216 & -0.055 & 0.0304 & 0.8258 \\
& $\mathrm{MC}$ & 7.9245 & -0.0824 & 0.9303 & $0.0355^{*}$ \\
\hline
\end{tabular}

$*=P<0.05, * *=P<0.01$.

Table 8. Relationship between crown cover and soil variables.

\begin{tabular}{|c|c|c|c|c|c|}
\hline Categories & & $\mathrm{a}$ & $\mathrm{b}$ & $\mathrm{r}^{2}$ & $P$ \\
\hline \multirow[t]{4}{*}{ Mixed deciduous forest } & $\mathrm{pH}$ & 502.0532 & -9.4683 & 0.0234 & 0.8472 \\
\hline & $\mathrm{OM}$ & 398.8979 & 15.294 & 0.9817 & $0.0092^{* *}$ \\
\hline & MC & 384.4447 & 2.2439 & 0.909 & $0.0466^{*}$ \\
\hline & $\mathrm{BD}$ & 583.3104 & -114.044 & 0.1638 & 0.5953 \\
\hline \multirow[t]{4}{*}{ Deciduous dipterocarp forest } & $\mathrm{pH}$ & -363.82 & 122.357 & 0.8575 & 0.074 \\
\hline & $\mathrm{OM}$ & 403.75 & -14.902 & 0.2726 & 0.4779 \\
\hline & MC & 517.162 & -7.2173 & 0.8724 & 0.66 \\
\hline & $\mathrm{BD}$ & 372.254 & 3.8699 & 0.0006 & 0.9759 \\
\hline
\end{tabular}

$*=P<0.05, * *=P<0.01$.

forest and deciduous dipterocarp forest. The crown cover and $\mathrm{pH}$, BD of mixed deciduous forest were not significantly related. The crown cover and soil variables (OM and $\mathrm{MC}$ ) of mixed deciduous forest were direct significantly related at $P<0.01$ and 0.05 levels. However, the crown cover and soil variables (pH, OM, MC, BD) were not significantly related in deciduous dipterocarp forest.

\section{Discussion}

Analysis of the forest inventory data of different vegetation types revealed that Tectona grandis had highest density, frequency and IVI in mixed deciduous forest and Dipterocarpus tuberculatus in deciduous dipterocarp forest because of these species were dominant species in respective forest types. In both vegetation types, the species with high IVIs showed good regeneration potential. This finding is in accordance with Whittaker's work [17], in which the dominance of one stratum may affect the diversity of another stratum. The diameter class distribution patterns for both forest types were in the form of reversed "J-shaped" curve, indicating the adequate representation of small trees in the lower diameter classes. The maximum numbers of species were encountered in lowest gird at breast height class $(10-20 \mathrm{~cm})$ while species numbers gradually decrease with increasing girth classes. In vertical structure, most species and individuals were concentrated in lowest height class due to diameter and high of trees are closely related. The population structure characterized by the presence of adequate number of seedlings, saplings and young trees depicts satisfactory regeneration behavior, while inadequate number of seedlings and saplings of tree species in a forest indicates its poor regeneration [18]. The regeneration potential of a species in a community can be assessed from the population dynamics of seedlings and saplings in the forest [19]. In the two forests, the sufficient amount of seedlings, saplings and trees in the smaller diameter 
class indicate the ability of these two forests to recruit into adult phase. As the mean soil moisture contents were assumed to differ between mixed deciduous forest and deciduous dipterocarp forest, there was significant difference in soil moisture contents between both investigated forests. It is possible that the mixed deciduous forest retained denser canopy than deciduous dipterocarp forest and this finding is in accordance with the findings of Abdallah, F., and Chaieb, M [20]. Soil moisture content is higher under more woody vegetation than those in less woody vegetation due to the positive effect of shade from the canopies. Bulk density values were significantly different between the two forests. The lower soil bulk density occurs in mixed deciduous forest because much more organic matter (OM) which derived from different kinds of tree species' little decomposed humus exists at that type of forest. The soil $\mathrm{OM}$ and total $\mathrm{N}$ contents of mixed deciduous forest were more concentrated than deciduous dipterocarp forest.

\section{Conclusion}

Mixed deciduous forest is more diverse than deciduous dipterocarp forest. In mixed deciduous forest, total density of seedlings, saplings and trees were much more associated than deciduous dipterocarp forest. It is clear that large amount of OM associated with dense canopy cover of mixed deciduous forest ecosystem. Moisture content of MDF related to denser canopy of moist deciduous forest's crown cover. Thus this finding can be used as a good indicator in identifying the better way for effective management of watershed forests and in monitoring as well as in subsequent evaluation of the study area. In order to attain for fresh and clean water for the future prosperity and good life quality of people living around watershed forests, it is urgent need to prevent landslide, to protect forest degradation and soil erosion, and to protect this watershed areas for effective watershed ecosystem management without timber extraction in the future.

\section{References}

[1] Parthasarathy, N. (2001) Changes in Forest Composition and Structure in Three Sites of Tropical Evergreen Forest around Sengaltheri, Western Ghats. Current Science, 80, 389-393.

[2] Swamy, P.S., Sundarapandian, S.M. and Chandrasekar, P. (2000) Plant Species Diversity and Tree Population Structure of a Humid Tropical Forest in Tamil Nadu, India. Biodiversity and Conservation, 12, 1643-1669. http://dx.doi.org/10.1023/A:1026511812878

[3] Van der Maarel, E. (2005) Vegetation Ecology-An Overview. In: van der Maarel, E., Ed., Vegetation Ecology, Blackwell Publishing, 1-3.

[4] Leps, J. (2005) Diversity and Ecosystem Function. In: van der Maarel, E., Ed., Vegetation Ecology, Blackwell Publishing, 199-203.

[5] Brady, N.C. and Weil, R.R. (2002) The Nature and Properties of Soils. 13th Edition, Pearson Education, Inc., Upper Saddle River, 960.

[6] Grigal, D.F. and Ohmann, L.F. (1992) Carbon Storage in Upland Forests of the Lake States. Soil Science Society of America Journal, 56, 935-943. http://dx.doi.org/10.2136/sssaj1992.03615995005600030042x

[7] Kress, J.W., Defillipps, A.R., Ferr, E. and Kyi, Y.Y. (2003) A Checklist of the Trees, Shrub, Herbs and Climbers of Myamnamr.

[8] Prichett, W.L. and Ohn, T.T. (1981) Manual of Laboratory Procedures for the Analyses of Soil and Plants, Technical document No. 6, Forest Research Institute, Yezin.

[9] Shannon, C.E. and Weiner, W. (1949) The Mathematical Theory of Communication. University of Illinois Press, Urbana.

[10] Simpson, E.H. (1949) Measurement of Diversity. Nature, 163, 688. http://dx.doi.org/10.1038/163688a0

[11] Magurran, A.E. (1988) Ecological Diversity and Its Measurement. Princeton University Press, Princeton. http://dx.doi.org/10.1007/978-94-015-7358-0

[12] Ludwig, J.A. and Reynold, J.F. (1988) Statistical Ecology. Wiley, New York.

[13] Sorensen, T. (1948) A Method of Establishing Groups of Equal Amplitude in Plant Sociology Based on Similarity of Species Content. Dent Kong Dansk Vindensk, 5, 1-34.

[14] Weidelt, H.-J. (1968) Der Brandhackbau in Brasilien und seine Auswirkungen auf die Waldvegetation. Diss. Forstwissenschaftlicher Fachbereich, Universität Göttingen, Göttingen, 163 p.

[15] Bray, J.R. and Curtis, J.T. (1957) An Ordination of Upland Forest Communities of Southern Wisconsin. Ecological Monographs, 27, 325-349. http://dx.doi.org/10.2307/1942268 
[16] Lamprecht, H. (1989) Silviculture in the Tropics. 296 p.

[17] Whittaker, R.H. (1972) Evolution and Measurement of Species Diversity. Taxon, 21, 213-251. http://dx.doi.org/10.2307/1218190

[18] Saxena, A.K. and Singh, J.S. (1984) Tree Population Structure of Certain Himalayan Forest Associations and Implications Concerning Their Future Composition. Vegetatio, 58, 61-69. http://dx.doi.org/10.1007/BF00044928

[19] Duchok, R., Kent, K., Khumbongmayum, A.D., Paul, A. and Khan, M.L. (2005) Population Structure and Regeneration Status of Medicinal Tree Illicium griffithii in Relation to Disturbance Gradients in Temperate Broad-Leaved Forest of Arunachal Pradesh. Current Science, 89, 673-676.

[20] Abdallah, F. and Chaieb, M. (2012) The Influence of Trees on Nutrient, Water, Light Availability and Understory Vegetation in an Arid Environment. Applied Vegetation Science, 15, 501-512. http://dx.doi.org/10.1111/j.1654-109X.2012.01201.x 